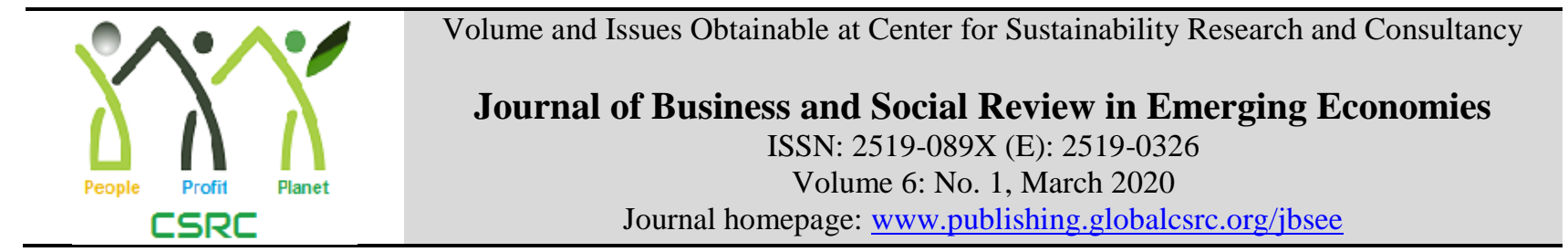

\title{
A Qualitative Analysis of Social Determinants of Entrepreneurship Success (Thematic Analysis)
}

\section{${ }^{1}$ Muhmmad Furqan Ashraf, ${ }^{2}$ Babak Mahmood, ${ }^{3}$ Ayesha Ch}

${ }^{1}$ PhD Scholar, Department of Sociology, GC University, Faisalabad, Punjab, Pakistan. furqanashrafsoc@gmail.com

${ }^{2}$ Associate Professor, Department of Sociology, GC, University, Faisalabad, Punjab, Pakistan

${ }^{3}$ Assistant Professor, Department of Sociology, GC, University, Faisalabad, Punjab, Pakistan

\begin{tabular}{l} 
ARTICLE DETAILS \\
\hline History \\
Revised format: February 2020 \\
Available Online: March 2020
\end{tabular}

\section{Keywords}

Entrepreneurship success, entrepreneurship intention and learning, entrepreneurial knowledge and experience, family support, qualitative exploratory case study, thematic analysis.

\section{JEL Classification:}

$\mathrm{N} 7, \mathrm{~A} 20$

\section{ABSTRACT}

This study has been conducted to explore the important social determinants of entrepreneurship success. Families' involvement is crucial for entrepreneurship success. The myth is prevailed in our society as successful life is to be opened as to secure a position in public or private sector. Social determinants are not discussed in detail before. To know what social determinants are important to equip success in business? Qualitative exploratory case study method (Yin. K, 2014) was used to explore social determinants in detail. Field notes were taken on note book with pencil and interviews were recorded personally by the researcher himself and these field notes and data were transcribed to document the important patterns and themes. Thematic analysis was applied to the data for analysis purpose. Findings of the study depicted that family business involve in entrepreneurial intention, role model provide supportive material, family financial help, prior business experience, entrepreneurship knowledge and understanding, were the important determinants of entrepreneurship success.At the end of the paper it was suggested that entrepreneurship training must be provided by the government institution and universities must induct degree program in entrepreneurship. Seminars and conferences on entrepreneurship awareness must be organized by nongovernmental organizations with the collaboration of government agencies and institutions.

(C) 2020 The authors, under a Creative Commons Attribution-

NonCommercial 4.0

\section{OPEN ACCESS}

Corresponding author's email address: furqanashrafsoc@gmail.com

Recommended citation: Ashraf, M. F., Mahmood, B., Ch, A. (2020) A Qualitative Analysis of Social Determinants of Entrepreneurship Success (Thematic Analysis). Journal of Business and Social Review in Emerging Economies, 6(1), 379-390

DOI: $10.26710 /$ jbsee.v6i1.1097

\section{Introduction}

The definition of entrepreneurship success has been defined in many ways by different authors. One comprehensive definition refers to as entrepreneurship success is associated with innovative behavior and advancement in country's welfare. Various factors are involved in entrepreneurial success as support from others, entrepreneurial success to information and leadership style encourage an individual towards success (Makhbul \& Hasun, 2011). According to a report Pakistan is a lower income country where per 
capita income is $1555 \$$ (Global Entrepreneurship Monitor, 2018). Achievement of business comes from its origin and describes as performance of business either it can fail or succeed. The ability to produce an object in relation to achieve a target in similar meaning of performance describes as success (Sefiani, 2013).

It is widely accepted that entrepreneurship plays an important role in economic development of any country. The number and competence affects the economic growth of a country. The fact is that the entrepreneur's encouragement and enthusiasm explores the state resources and utilize them to make more profit (Dhaliwal, 2016). Secure profit and use of resources optimizes positive relationship between entrepreneurship and economic growth (Ahiauzu, 2010) at the same time as (Henderson, 2006) describes entrepreneurship as progressively more acknowledged and crucial engine of economic growth. By combining active possessions with inventive ideas, entrepreneurs add worth during the modernization of new products, the conception of new jobs, and establishing new firms. Adding, role of the entrepreneur in moving out innovations and in enhancing competition is significant for economic growth (Wennekers \& Thurik, 1999).

\subsection{Objective of the study}

- To explore determinants of entrepreneurial success.

\subsection{Research Questions of the study}

1. How did you start your business?

2. Why did you choose business?

3. Who inspired you towards making your intention about entrepreneurship?

4. What hurdles and challenges did you face?

\section{Review of literature}

\subsection{Family Background and Entrepreneurial Intention}

Numbers of factors are involved in entrepreneurial success and develop entrepreneurial intention. Family background has been considered as one of the major factors to encourage an individual to go through into a business, existing or new. Family culture where innovating views have been productively converted into immense business territory or an enormous prosperity for them and offspring tends to examine a tradition which they need to take entrepreneurial initiative. Entrepreneurship intention (EI) has been developed thorough socialization that the family interaction and involvement in early age of the entrepreneurs' leads to encompass (EI). A work reported by (Pant, 2016)and stated that persons with entrepreneurial ancestors enclose with higher entrepreneurial intention (EI) and having higher rate of becoming an entrepreneurs and also held very limited time to establish their business. In the same vies Ahmed et al. (2010) found that an individual with entrepreneurial experience or entrepreneurial family background inserts more propensities to entrepreneurial career. Family environment with business exposure habitually inclines and motivates their offspring to engage in entrepreneurial action and they are expected to encompass advanced expectations to start a business (Carr \& Sequeira, 2007).

\subsection{Social Vision and Self Confidence}

According to work stated by Guler (2010) social vision about to start any business was also considered as the most important and essential subject differentiating social entrepreneurship as problem solving than other types of entrepreneurships (Nga \& Shamuganathan, 2010) states that experience in which the social entrepreneurs had been thought in their earlier period that represents the reason why social entrepreneurs was aimed to resolve social problems or why social entrepreneurs appreciated these problems easily and compared to other people only through visionary approach. Further in connection with self confidence presumes belief in individual judgment that is required and necessary to perform an action. A study conducted by Turker \& Seluck (2009) and depicted that it was valuable asset for an individual who actually belief in their actions with confidence. Further make people happier and emotionally sustain stimulations convince others. Pursuing important goals and wants in life based on self belief and confidence. Asoni (2011) stated that increase in business creation and innovative ideas cohabited with self 
confidence that was considered inevitable. Therefore, individuals who capture more confidencehave higher intention and success in entrepreneurship. This statement was also supported by Chen (2014) who concluded that self confidence enhancedmore intention towards entrepreneurship by collaborating with self belief.

\subsection{Entrepreneurial Knowledge, Education and Learning}

The culture of entrepreneurship reflects by the available opportunities of self employment in country. So the entrepreneurial environment preferably education system provides knowledge about entrepreneurship, (Premnath, (2016) endorsed this concept and viewed that effectually in persistent global business environment put a lots of discrepancies in modern thoughts of self employment. In connection to environment social, political and economic situation is best suited to perform better entrepreneurial growth, or impede entrepreneurial activities in society. Willingness and abilities of entrepreneurs connect with performance and undertake entrepreneurial activities (Gnyawali \& Fogel, 1994). Lack of availability of physical infrastructure like water, gas, electricity and roads reflects poor environment for entrepreneurship growth (Agboli \& Ukaegbu, 2006) and deficiency in human and material sources skews non operational successful entrepreneurial activities (Abimbola \& Agboola, 2011).

Learning behavior of entrepreneurship comes from experience through environment in which individual is living. According to a study conducted by Politis (2005) found that entrepreneurial career and experience acknowledge through entrepreneurial process proceeded activities for future entrepreneurial success. This work was coincided by (Malekovic et al., 2016) reported that mind set and creative thinking enhanced the ability to perform ambitious development of self employment.

\section{Research Design, Study Setting and Participants}

This was a pure qualitative research study on successful entrepreneurs. Punjab is considered as high income generated provinces of in Pakistan. After Karachi and Lahore, Faisalabad is considered as big trading and business hub of Pakistan, also a largest producer of textile manufacturing products and other related business as well. Despite the fact, District Faisalabad is popular and full of business chunks and that was study area of current research, where number of successful entrepreneurs could easily be approached. In order to collect data, four case studies were conducted only with successful entrepreneurs. No further inclusion criteria were focused to approach study participants therefore, only successful entrepreneurs from different places and who were convenient to participate in study were interviewed. The available sight with light and sitting capacity was observed before getting interview from the participants.

\subsection{Data collection}

The pioneer of modern case study method in social research (Yin, 2014), the process of case study was used to complete this piece of work. By him, in most recent academic and scholarly studies that are conducted on contemporary issues, especially in management as unemployment, entrepreneurship and medical issues, according to these issues case study method was most widely used in exploratory research. When a researcher seeks to get answers of what, why and how questions, this method provides holistic view of under research event, phenomena or issue.

Open ended unstructured interviews were conducted for collection of the data. Field notes were taken to save interview data on copy with pencil. Important contents of the interviews were written and more deliberately with conscious effort were made to equip more information regarding entrepreneurship success in holistic way; focus was being made on each and every view, belief and experience of subjects.

\subsection{Data analysis}

After collecting the data, filed notes were organized into prescribed form. The transcription of data is first and fundamental process to familiarize with the collected data and this process is also fruitful to understand important patterns and themes. After familiarizing with the collected data, important codes to patterns or text were given manually, these codes highlighted the important patterns from the transcribed text and these patterns were further organized into themes. Six important themes explored and discussed. Demographic status of successful entrepreneurs (table 1) mentioned below. 
Table 1: Socio- Demographic description of participants

\begin{tabular}{|c|c|c|c|c|c|c|}
\hline $\begin{array}{l}\text { Participants(all } \\
\text { males) }\end{array}$ & Age & Education & $\begin{array}{l}\text { Residential } \\
\text { Location }\end{array}$ & $\begin{array}{l}\text { Business } \\
\text { Experience }\end{array}$ & $\begin{array}{l}\text { Family } \\
\text { Business }\end{array}$ & $\begin{array}{l}\text { Financial } \\
\text { Assistance }\end{array}$ \\
\hline 1A & 38 & MBA & Urban & 14 Years & Yes & Yes \\
\hline 2A & 55 & BA & Urban & 10 Years & Yes & Yes \\
\hline 3A & 48 & B.com & Urban & 11 Years & Yes & Yes \\
\hline 4A & 32 & BBA & SemiUrban & 13 Years & Yes & Yes \\
\hline
\end{tabular}

Above table indicates that all respondents were between the ages of 32-55, while there educational level was found incredible as they were well known with the word of entrepreneurship and business. All participants were belonged to urban area of Faisalabad city. The fact is also to be notable that all participants have at least ten years of experience at the time when got interviewed. All study participants answered about the questions that have been asked for describing their socio demographic profile, as they all had business experience before starting and entering in the pipe line of successful entrepreneurship. The data in table also shows that they had family business, as all participants respondedthat they have family business and also had financial support from their families for business. In the light of their experiences some important themes were generated and discussed.

\section{Themes and Discussion}

\section{Theme 4.1:- Familial Business Involve in Entrepreneurial Success.}

Family business characteristics accounted for responsibility of entrepreneurial activities and entrepreneurial intention. Majority of the respondents shared their experiences that they had family business culture, a lot of values about business got from their families during socialization. It has been described that family culture involve in entrepreneurship success. Already established businesses got involved their next generations into business, this is very easy and efficient for successful entrepreneurs to make a part of their established businesses for its further extension and development into family businesses as well.

As one of the participant said that:

"My father was engaged in family business for many years. He wanted me to get involve in business, and after doing much personal struggle in my own life, I engaged myself in my family business. I tried myself for getting job in private institutions, when I was 12 years old, I thought about to become a banker to give the loans to others, because of my mother s brother who was serving in a private bank and getting enough income, when I was in my childhood I followed and acted like him"

One of another respondent shared that:

"In order to make social vision of entrepreneurship intention, my family put me a lot of confidence and clarity about entrepreneurial behavior. My clear vision of doing business supported me to grip with strong gestures for this business culture. My socialization equipped in entrepreneurial environment where my father put on me a lot of pressure to do self business rather than pursuing job as an employee. My father remained a big opponent of getting any job, so I never felt relax to seek or find any job".

Entrepreneurial will and personal ambition enhance personal vision towards entrepreneurial intention. Learning business norms and values by socialization process residing in business family environment added business

\section{Theme 4.2:- Role Model Specifies Supportive Entrepreneurial Activity and Intention}

This is an individual decision to become an entrepreneur. Most entrepreneurs have been inspired by someone in his life. Therefore, family business provides role models for future entrepreneurs. The role model gives a direction to an individual which also develops intention towards entrepreneurship.

One of the participants said that:

"My uncle was a role model for me, who took me his shop, where I worked for many years and got 
a lot of experience from him. I also learnt that how he was good in financial management, as estimate correctly the whole expenditure of shop on weekly bases. In the eyes of him I had developed working experience and he ought to be said that about that I would developed my own business one day, because of my involvement in business. I thought this was made possible because of my uncle whose efforts and belief on me boost me up to rise in the sky and gave me a lot of respect and confidence and had the risk taking ability”.

Another participant shared his experience as:

"My father was role model for me, because he served as government officer, he did work very hard with solid intention of doing their routine work. Similar capacity of solid intention for doing the work that I got from them. This element was being a motivational factor for me every time, and I went for taking risks, and now I am doing business for many years. He further added that, parental role every time made my intention more clearly towards boosting me up for successful business".

On the behalf of interview one of another participant added that:

"Someone who was being near to you, expand functions with presence of another individual who observed him and follow or copy him as successful entrepreneurs did. My father and his friend and my uncle were role model for me. When I was child, my father insisted me to get education, after completion of BBA, I worked for three years at my uncle shop. He advised me to open a new shop at new location of the city. I shared with my father, my father further motivated and sent me to his friend for loan through a bank, after getting loan and opened an electronic shop. During my stay at my uncle shop I had developed social relations with all clients who ever visited on our shop and this social networking behavior helped me to settle independently at my business.

One of another participant shared his experience as:

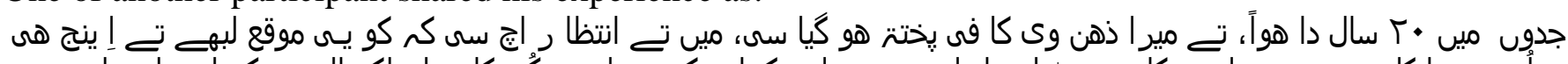

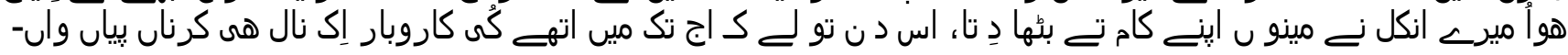

Translation into English: He further reported that "when I was at 20 years old, my business thinking had been developed, and I was waiting the opportunity, then my uncle handed over his business to me. From that day, I am here and successfully doing multiple businesses".

Above theme clearly indicates the importance of role model in developing personal intention towards entrepreneurship. A person can learn from following their experiences of doing business, in supporting persona will of doing entrepreneurship or venture creation role model boost up an individual towards entrepreneurship success.

\section{Theme 4.3:- Social and Moral Support Through Social Network for Entrepreneurship}

Family support is crucial for entrepreneurial success. Family moral support strengthens a person with static and dynamic intentions for doing something that may be not possible in harsh and complex circumstances. Social contacts and social network of family relation are more beneficial for entrepreneurial development and success. Therefore, family social capital through family personal contacts has positive consistent effect on entrepreneurial start-up.

One of the participants shared his experience as:

"Families with entrepreneurial knowledge act as a source of moral support for inspiration of entrepreneurs in difficult times. Family social network of peers, friends, relatives support and motivation enhances an individual to boost up with courage, when an individual stuck in entrepreneurial problems. For instance, in Pakistan people who belong to a Sheikh family, prepared for doing their own business rather than getting a job. The reason behind this increasing rate of doing business by the Sheikh family is moral, social and economic support by the family".

One of the participants said that:

"When I had made an intention for doing a business, my father moral support strengthen and encouraged me that boost up my confidence level. With this confidence I started my business also having support other family members. I followed directions from my parents for starting business and some time consulted problems and issues with them, my family was being very kind for in the 
journey of business. This was also very important to me my relatives also supported me with provision of different kind of help".

"Entrepreneurship requires support, linkages or associations between key mechanisms of processes. People are more elegant to expand social ties or share networking with people in order to support their businesses. that similar outline that was created in most of under developing countries including, where social network was being considered as very important determinant of influencing entrepreneurial behavior and intention of individuals, support of peers, business partners and working environment are found to be comprehensively persistent in results".

"Families with entrepreneurial knowledge act as a source of moral support for inspiration of entrepreneurs in difficult times. Family social network of peers, friends, relatives support and motivation enhances an individual to boost up with courage, when an individual stuck in entrepreneurial problems. For instance, in Pakistan people who belong to a Sheikh family, prepared for doing their own business rather than getting a job. The reason behind this increasing rate of doing business by the Sheikh family is moral, social and economic support by the family".

\section{Theme 4.4:- Financial Self Support from Family}

There have been discussed two mediums of entrepreneurship financing. The first, internal financial management, by the family of entrepreneurs, peers, relatives' and form social network. Family financial assistance is a positive indicator to make entrepreneurial intention and success. Most of the literature on this issue has been confirmed that the most essential financial provider is the entrepreneurial financial self efficacy of families. External financial assistance can be taken as loan from private and public loans.

One of the participants shared that:

"My family was belonged to self business from many years, when I made my intention towards starting my business, my family financially helped me. No any financial matter impeded me towards start-up. Once I thought about to get loan from bank or anyone else from out of my family as, but higher rate of interest on loan imposed by main bank It was remained impossible to get loan from bank".

Another participant said that:

"I got money from elder brother who was dealing in business for many years, with the consent of my father and my uncle who were already dealing in construction business."

\section{Theme 4.5:- Prior Entrepreneurial Knowledge and Education}

Family background also involves providing fundamental entrepreneurial knowledge that promotes entrepreneurial intention toward initiating a business. Entrepreneurial learning from family through informal means generate more effective attempts for starting a business. Distribution of information is very important in this global world. Through education, entrepreneurs can also identify different activities for entrepreneurial success. New business opportunities can easily be traced via entrepreneurial knowledge that cannot be traced without prior knowledge. One of the participants said that:

"I have completed my MBA degree in marketing, afterward, I tried to get a job in banking sector, once I got a job offer from a private bank, I discussed the matter with my father, and my father refused me to get any kind of job in any organization. Besides, my father did not talk to me for many days. Then I thought that I have an MBA degree and had knowledge about entrepreneurship, started work with my father's business".

One of the participants said, who was belonged to a Sheikh family by caste.

"My many relatives are doing multiple businesses, mostly are dealing in readymade cloths, and fewer are dealing in "raw cloth". When I was 9 years old I had to go on my father's shop. I learnt and found the answers of some basic question related to business. The questions were that how, when and why to do business? I judged working of my father and my real uncle who was the husband of my father's sister, after watching them for many years they were go for doing business at evening. Once I listened to my father who was saying to my uncle that my elder brother was growing fast, I must go him with me at evening, where he would get 
experience of dealing in business of raw cloth. In this way I learn about business and education get through non formal means the medium of my learning was my family education.

This theme documents the importance of entrepreneurial knowledge and education. Doing business is not a easy job, because of education from family for making intention and will toward doing business. Educational institutions for transferring the entrepreneurial knowledge are big sources; therefore informal means of getting knowledge through their families are also crucial for entrepreneurial behavior.

\section{Theme 4.6:- Prior Experience of Business to create Self Belief}

No doubt, past experience promotes an entrepreneurial personal self efficacy toward further entrepreneurial learning and success. Self efficacy was defined as belief on personal abilities, experience and intention. A person can take new business actions and produce entrepreneurship intentions only when self-efficacy towered concerning on a definite occasion. Prior entrepreneurship self belief encompasses and elevates personal intentions to create new business and having determination in appealing into entrepreneurial actions. The entrepreneurial success was based on entrepreneurial learning, entrepreneurial self efficacy, skill and experience.

In the same scenario, one of the other participants added that:

"Before starting my business, I had worked for two years with my uncle, who motivated me first. After spending two years here with my uncle shop, I did belief on myself, also got market dealing experience, developed network in market, afterword I started my business". Self belief on my daily dealing practice made me more confident and prior experience helped me in positive manner.

To create self belief on your actions and behavior this is considered most obvious to approach experience of any business, which you want to start in future. Without lack sufficient experience failure rate gone high and uncertainty avoidance decreases.

Another participant shared his experience as:

"I worked on mobile shop for many years and got a lot of experience during my stay at mobile shop of my neighbor, my neighbor was dealing with mobiles for many years. My father was dealing with property; this profession was not being a good enough for my family. I was only children of my parents".

He further added that "When I grow up at 16 years old, I could feel my family financial alertness form my father, but my father never ordered me to do any work; he wanted me to become an officer in public sector. After having this situation my own will of doing business aroused and I discussed with my neighbor who is my business partner now, then at that time when I was discussed the matter he was dealing with mobile shop from many years. I went on his shop and got experience of getting training of mobile hardware and software. After getting training and experience I separately opened my repairing shop in bazaar, from that day I was here earning enough".

The success in business is no doubt without experience cannot achieve or very hardly. Personal past experience is grounded on learning and doing business no more because of disintegration of business towards success. Entrepreneurship intention through past experience makes self belief and determination of efforts for entrepreneurial success.

\section{Discussion}

There is immense literature on entrepreneurial intention and learning of entrepreneurial behavior through entrepreneurial education and experience, but was not clear in social facets in the case of Pakistan. Hence, this study examined and contributed in existing literature that how entrepreneurs got success in their small businesses and gain the status of successful entreprneurs. Study results are coincided with past literature for making inferences between concept and themes of study and also to make clear picture of social determinants that are involved in entrepreneurial success. Asentrepreneurial learning is a procedure by which people obtain, understand, and arrange newly produced information with prior structures, and how education and knowledge affects entrepreneurial action (Cope, 2005; Corbett, 2007; Rae \&Carswell2001; 
Warren, 2004). In the same scenario Karimi et al., (2102) supports the results that entrepreneurship education program in educational institutions influenced on personal behavior toward doing entrepreneurship. Entrepreneurship education condition equipping individuals with the skills and knowledge for entrepreneurial start-up that has been exposed for increasing requirement in higher education (HE) and are documented as competence enhancers for entrepreneurial development (Wilson et al., 2009).

In this milieu,Basu (2004) coincide the claim that the effects on entrepreneurial knowledge by family value ambition as it has been prepared in the family business succession and considered the family affection with business success, diversification in desire of entrepreneurial behavior remained possible outcome; diversity might be existed between family values, class, and self-employment knowledge and experience. For entrepreneurship intention that predicts success of entrepreneurs coincides with the work of (Pant, 2015) that family has its positive and growing impact on entrepreneurship success for next generations, and choices of entrepreneurship careers through parental entrepreneurial profession was sustained. In the same scenario another study conducted by Aldrif and Cliff (2003), and concluded that entrepreneurial network of social relations was key for entrepreneurial success. In connection to this evidence Ahmad et al. (2010) stated that family provides a key roleto attribute and characteristics for future entrepreneur's success. The most successful entrepreneurs belong to family business, have knowledge of what type of business might be possible, it made possible through family support. Nobrega\&Hoffeman (2014) added that family business got unique context and encouraged to their next generations to involve in entrepreneurial activities (Rani, 2012) also observed that the intention of an individual which might be determined by his planned behavior, and it has also been ensured that family support and role model influence the entrepreneurial inclination among successful entrepreneurs.

So, the intention of entrepreneurs become self confident to entrepreneurs and increase in creation business ideas and innovation that is inevitable without family involvement. Individuals who capture more confidence have higher intention and success in entrepreneurship. Self confidence enhances intention towards entrepreneurship for making clear social vision about starting business venture. However, the main factor differentiated the vision of social entrepreneurs and charity deeds was the fact that social entrepreneurs intended to get to the foundation of the problem and target to create a long lasting process for resolution (Guler, 2010).

In connection to family involvement two considerations were evidenced as:

First, the importance of role model for making an intention for entrepreneurial business success belonged to family association. Parenting role model, peer and relatives as role model put positive association with entrepreneurial success and entrepreneurial intention. Second, role model provided the rope of literature and depicted that the role models functions connected with the decision to become an entrepreneur that was attained from further collective viewpoint than that of an individual.

Consequently, the resemblance between entrepreneurs and their role models has not been studied before. Entrepreneurs have done following role models, who were similar to entrepreneurs themselves in terms of characteristics such as experience and functions, may they did select role models that were different innovative with a more inspiration and action These ropes of evidences purely proposea relation between the activeness of role models and the intention based decision to become an entrepreneur. These entrepreneurs may honestly ascertain contact between role model activeness and new entrepreneurial start up. Adding more, evidence based researches concluded thatrole models may provide a process by entrepreneurs to start new business. Siemon et al. (2016) indicated that role model is very important supportive material to perform creativity opportunity and creativity support system to start up a new enterprise or business success. This can also lead to the expansion of innovative thought and also lead to useful product and services that can essentially needful for provision entrepreneurial accomplishment.It has been evidenced that the relationship and social network (Parker, 2009; Gianetti\& Simonov, 2009) influenced the intention and learning behaviour employs decision of entrepreneurship, while it was observed that social relation and network provide through role model of individuals. 
Financial possessions were populated as the family financial return for new venture creation (Steier, 2003). In response, family members are frequently supposed to be the most appropriate providers of financial resources (Astrachan et al., 2003; Bygrave et al. 2003; Coleman \& Robb 2011) as most of the participants said that they employed the financial assistance of family for setting up their businesses it was also necessary because of financial assets from family members probably has significant compensation such as lower transaction problems or easy access and no fear of loss (Au \& Kwan, 2009), it also approves the interest and payback requirements accessibility when other sources are not accessible (Steier\& Greenwood 2000). Resultantly, the discussion tends to suppose perfectly that the additional capital commencing the family members are available and the more possibility to be entrepreneurial success.

\section{Conclusion}

This research explored the number of social determinants that are involved in entrepreneurship success. It has found that family business involvement put moral and social support to the entrepreneurs in learning and making personal intention towards entrepreneurship. It has also found that all the successful entrepreneurs were aware of entrepreneurship and had understanding about the word through family socialization and via formal education. The study depicts that effects of family background, prior business experience, role model from family and peers, and know how about entrepreneurship enhanced the ability and personal self efficacy towards thinking, practicing, and making an intention to entrepreneurship. Entrepreneurial learning has in this torrent of study mainly been equal to comparing the comparative consequence of entrepreneurs' experience at a given point of time, and then to narrate this reserve of incident to variations in new endeavor performance. It is also essential to recognize that experience does not openly direct a business initiative either entrepreneurial knowledge is acquired for entrepreneurship success. In order to gain new experiences and the expansion of new information might be described as a partial process then experiences of family businesses being transformed into next generation to understand the ability and wisdom of entrepreneurs. Entrepreneurial learning is subsequently the query of how entrepreneurs convert understanding into entrepreneurial knowledge, which obliquely is a positive impact on the consequent presentation of a new enterprise development. The affects of these determinants on entrepreneurial success by providing family involvement, financial support, also employs many recognize opportunities into their environment. The themes of the study were consistent and now clear with many earlier studies that have been discussed. It is also concludes that different impediments are responsible for entrepreneurial failure and success, from these impediments most of successful entrepreneurs made use of available opportunities for entrepreneurial success.

\section{Recommendations}

1. To keep aware about importance of entrepreneurship government must hold the conferences and seminars in universities with the collaboration of civil society participation.

2. Entrepreneurship intention based model must be developed to know the intention and future behavior of young graduates about entrepreneurship.

3. Future entrepreneurs must intact with successful entrepreneurs and get experience after completion of education.

4. National Curriculum on entrepreneurship must be developed and degree programs must be launched in major universities of Pakistan

\section{For Future Research}

5. Higher education commision must provide funding for the project on the importance of social entrepreneurship.

6. The sample of the study must be expand, therefore more qualitative case studies must be conducted on successful entrepreneurs; and more deliberate efforts must be done to know the behavior of successful entrepreneurs. 


\section{References}

Abimbola, O. H., and Agboola, G. M. (2011). Environmental factors and entrepreneurship development in Nigeria. Journal of sustainable development in Africa, 13(4).

Agboli, M., and Ukaegbu, C. C. (2006). Business environment and entrepreneurial activity in Nigeria: implications for industrial development. Journal of modern African studies, 4(1), 1-30.

Ahiauzu, A. (2010). Entrepreneurship and economic development in Nigeria: The way forward. In A. Ahmed and S. Nwankwo (Eds.) Achieving sustainable development in Africa (278-296). London: WASD.

Ahmed, I., Nawaz, M. M., Ahmad, Z., Shaukat, M. Z., Usman, A., Wasim-ul-Rehman., \& Ahmed, N.(2010). Determinants of Students' Entrepreneurial Career Intentions: Evidence from Business Graduates. European journal of social sciences, 15(2), 14-22.

Aldrich, H. E., \& Cliff, J. E. (2003). The pervasive effects of family on entrepreneurship: toward a family embeddedness perspective. Journal of business venturing, 18, 573-596.

Anderson, A., Dodd, S., \& Jack, S. (2009). Aggressors; winners; victims and outsiders: European school's social construction of the entrepreneur. International small business journal, 27(1), 126-136.

Asoni, A. (2011). Intelligence, self confidence and entrepreneurship. Research institute of industrial economics. Retrieved from: http://www.ifn.se/wfiles/wp/wp887.pdf

Au, K., \& Kwan, H. K. (2009). Start-up Capital and Chinese Entrepreneurs: The Role of Family, Entrepreneurship. Theory and practice 33(4), 889-908.

Astrachan, J. H., Zahra, S. A., \& Sharma, P. (2003). Family sponsored ventures. First Annual Global Entrepreneurship Symposium, New York, NY.

$\underline{\text { Basu, }}$ A. (2004). Entrepreneurial aspirations among family business owners. International journal of entrepreneurial behaviour\& research, 10(1/2), 12-33.

Bygrave, W. D., Hay, M., Ng, E., \& Reynolds, P. (2003). Executive Forum: A Study of Informal Investing in 29 Nations Composing the Global Entrepreneurship Monitor, Venture Capital, 5(2), 101-116.

Carr, J. C., \&Sequeira, J. M. (2007). Prior family business exposure as intergenerational influence and entrepreneurial intent: a theory of planned behavior approach. Journal of business research, 60(10), 1090-1098.

Chen, L. (2014). Understanding it entrepreneurial intention: an information systems. Journal of computer information systems fall 2014, 2-12.

Coleman, S., \& Robb, A. M (2011). Financing strategies of new technology-based firms. Review of economics and finance, 4, 1-18.

Cope, J. (2005). Toward a dynamic learning perspective of entrepreneurship. Entrepreneurship theory and practice, 29 (4), 373-97.

Corbett, A. C. (2007). Experiential learning within the process of opportunity identification and exploitation. Journal of business venturing, 29(4), 473-91.

Dhaliwal, A. (2016). Role of entrepreneurship in economic development. International Journal of scientific research and management, 4(6), 4262-4269.

Gianetti, M., \& Simonov, A (2009). Social Interactions and Entrepreneurial Activity. Journal of economics and management strategy, 18(3), 665-709, doi: 10.1111/j.1530-9134.2009.00226.x

Global EnrtrepreneurshipMonior (2018). Country profile. Retrieved from https://www.gemconsortium.org/economy-profiles/pakistan

Gnyawali, D. R., \&Fogel, D. (1994). Environment for entrepreneurship development, key dimensions and research implications. Entrepreneurship theory and practice, 18, 43-62.

Guler, B. K. (2010). Social entrepreneurship, Ankara: Efil Publishing.

Karimi, S., Harm J.A., Biemans, Lans, T., Mulder, M., \&Chizari, M. (2012). The role of entrepreneurship education in developing student's entrepreneurial education. Berenschot.com

Makhbul, Z. M., \&Hasun, F. M. (2011). Entrepreneurial Success: An Exploratory Study among Entrepreneurs. International journal of business and management, 6(1), 116-125.

Malekovic, S., Tisma, S., and Keser, I. (2016). The importance of entrepreneurial learning on the example 
of the South East European center for entrepreneurial learning in Crotia. The European journal of applied economics, 13(1), 60-71, doi: 10.5937/ejae13-8885

Nobrega, G. J., \& Hoffmann, V. E. (2014). Family businesses and the creation of entrepreneurship through their internal resources. RPCA, Rio de Janeiro 8(2) 92-105.

Nga, J.K.H., \&Shamugnathan, G. (2010). The influence of personality traits and demographic factors on social entrepreneurship star up intentions. Jounal of business ethics, 95(2), 254-282

Pant, S. K. (2015). Role of the family in entrepreneurship development in Nepali society. The journal of Nepalese business studies, 9(1), 37-47.

Parker, S. (2009). The Economics of entrepreneurship, Cambridge University Press, Cambridge, UK

Politis, D. (2005). The Process of Entrepreneurial Learning: A Conceptual Framework. 399-424

Premnath, S. (2016). Entrepreneurial Environment.pdf. Perspectives on Entrepreneurial Resurgence \& Innovations.

Retrieved

from. https://www.academia.edu/38287635/Entrepreneurial_Environment.pdf

Rae, D., \& M. Carswell. (2001). Towards a conceptual understanding of entrepreneurial learning. Journal of small business and enterprise development, 8(2), 150-8.

Rani, S. H. B. A. (2012). A study of relationship between family support, role model, and familial support towards entrepreneurial intentions among UUM-non-business students. Unpublished student thesis.

Sefiani, Y. (2013). Factors for Success in SMEs: A Perspective from Tangier. University of Gloucestershire.

Siemon, D., Narani, S. K., Ostermeier, K., \&Robra-Bissantz, S. (2016). Creativity and entrepreneurshipthe role of creativity support systems for start-ups. MCIS 2016 Proceedings, 24.

Steier, L. (2003). Variants of agency contracts in family financed ventures as a continuum of familial altruistic and market rationalities. Journal of business venturing, 18(5), 597-618

Steier, L., \& Greenwood, R. (2000). Entrepreneurship and the Evolution of Angel Financial Networks. Organization studies, 21(1), 163-192.

Turker, D. \&Selcuk, S. S. (2009). Which factors affect entrepreneurial intention of university students?, Journal of European Industrial Training, 33 (2), 142-159

Warren, L. (2004). A systemic approach to entrepreneurial learning: An exploration using storytelling. Systems research and behavioural science, 21 (1), 3-16.

Wennekers, S. \&Thurik, R. (1999). Linking Entrepreneurship and Economic Growth. Small Business Economics, 13(1), 27-56.

Wilson, F., Kickul,J. \&Marlino, D. (2007). Gender, entrepreneurial self-efficacy, and entrepreneurial, career intentions: implications for entrepreneurship education. Entrepreneurship theory and practice, 31(3), 387-406.

Yin, R. K. (2014). Case study research: Design and methods (5th Ed.). Thousand Oaks,CA: Sage Publications 
